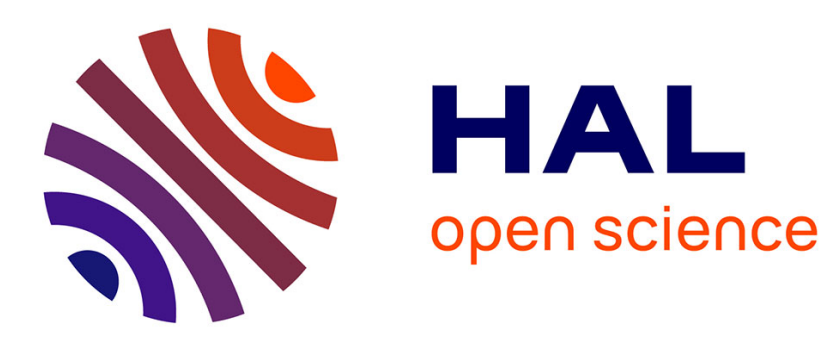

\title{
Time-frequency-energy analysis of ultrasound waves generated and detected by laser: application to quality control
}

\author{
H. El Mekki, J. Longuemard, M. Unal, J. Houle
}

\section{- To cite this version:}

H. El Mekki, J. Longuemard, M. Unal, J. Houle. Time-frequency-energy analysis of ultrasound waves generated and detected by laser: application to quality control. Journal de Physique IV Proceedings, 1994, 04 (C7), pp.C7-765-C7-768. 10.1051/jp4:19947180 • jpa-00253242

HAL Id: jpa-00253242

https://hal.science/jpa-00253242

Submitted on 1 Jan 1994

HAL is a multi-disciplinary open access archive for the deposit and dissemination of scientific research documents, whether they are published or not. The documents may come from teaching and research institutions in France or abroad, or from public or private research centers.
L'archive ouverte pluridisciplinaire HAL, est destinée au dépôt et à la diffusion de documents scientifiques de niveau recherche, publiés ou non, émanant des établissements d'enseignement et de recherche français ou étrangers, des laboratoires publics ou privés. 
Time-frequency-energy analysis of ultrasound waves generated and detected by laser: application to quality control

H. El Mekki, J.P. Longuemard, M. Unal* and J.L. Houle*

Laboratoire d'Electronique, Physique Appliquée et Productique, Ecole Centrale de Paris, Grande Voie des Vignes, 92290 Châtenay-Malabry, France

* Département de Génie Electrique et Informatique, Ecole Polytechnique de Montréal, Canada

\section{Abstract}

Ultrasounds are generally used in non-destructive testing (NDT) with sensors working with a narrow bandwith. The optical sensors generate and detect acoustical waves without contact and allows measurements in a wide band of frequencies. From this fact, the information contained in the signal captured is complete and give informations (celerity calculated by the time arrival of acoustical waves, attenuation and defect presence). The timefrequency-energy analysis is efficient for the acoustical waves comportment analysis in samples.

\section{Résumé}

Les ultrasons sont utilisés classiquement en CND avec fluide de couplage à des fréquences fixes déterminées par les capteurs eux mêmes. Des moyens optiques ont été utilisés pour générer et détecter les ultrasons sans contact, et dans une large bande de fréquence. De ce fait, les renseignements contenus dans un écho sont riches, outre la célérité déterminée par temps de parcours des ondes acoustiques, il est possible d'obtenir des données concernants l'atténuation ou la présence de défauts. L'analyse temps-fréquence-énergie est efficace pour étudier le comportement acoustique des ondes dans un échantillon.

\section{Introduction}

The genaration and detection of ultrasounds by laser are the subject of studies in the behaviour of laser matter and it associated technologies. Although an interferometer sensor by its principle (Michelson, fabry-Perot, Mack-Zehnder) detects a speed and an elongation, the behaviour at the emission is much more delicate. In fact, the optical wavelength of the emitter, the nature of the material, the state of the surface, the angle of inciedence, and rugosity (roughness) all have an influence. Previous studies [1] have shown that a $\mathrm{CO}_{2}$ TEA impuls energy source of $60 \mathrm{~m}$ and of pulse duration of 90 ns can produce at the focal point an acoustical signal for different types of material even with surfaces of high rugosity or covered with deposits [2]. In that frame work a 
source produces, depending on its energy density, either a thermoelastic state generating ultrasound waves with transversal dominance, or a state of microablation generating waves with compression dominance.

\section{Experimental method}

Research ont he effects produced by a fault can be conducted in different ways. In that fram work, we have chosen to study the acosutical behaviour of targets with or without defaults who's dimensions vary in comparison with different cases. In so doing, the measurement set-up must include three essential elements (figure 1):

- The emission produced by a source of $60 \mathrm{~m}_{\mathrm{J}}$ of energy lasts $90 \mathrm{~ns}$, wich an average peak power of $0.66 \mathrm{MW}$. The energy density is of the order of many hundreds of $\mathrm{KW} / \mathrm{mm}^{2}$. The micro-ablation mode is obtained at the focal point without destruction problems detectable with the naked eye, wich is not generally constricting for elements of general machanics ;

- The data acquisition is done with an electronic board sampling at $24 \mathrm{MHz}$, with a memory of 64 Kbytes. The highest ultrasound frequency is $10 \mathrm{MHz}$ wich is sufficient in very many NDT applications.

- The signal analysis is done as follows :

- Preleminary numerical filtering if required,

- Determination of the path time of the first echo coming either from the end of the tested part, or from a diffusion on a fault;

- Time-frequency-energy analysis [3-6] in order to establish the influence of the fault.

\section{Experimental results}

We have used a duralumin part of $100 \mathrm{~mm}$ in length and $20 \mathrm{~mm}$ in diameter, with a drilled through hole at $60 \mathrm{~mm}$ of the emission point. The reception is done with an interferometric sensor at the base of the cylinder opposite to the emission point (Figure 1). The acoustical signals with or without defaults have been filtered with a triangular band-pass filter [0.2-5 $\mathrm{MHz}$ ] (Figure 2).

We have been interested in a fast method of quality control where the positioning and dimentionning of a default is expected. We have studied spectrum differences in the time-frequency-energy space based on the sliding window Fourier Transform (SWFT) which uses rectangular-window functions. The algorithm consists in cutting the signal into succesive time slices and to apply a standard "Fast Fourier Transform" (FFT) on each slice. The spectral contents are then obtained within the window interval (fixed at the beginning). The SWFT is then computed by translating that window along the time axix. The introduction of a fault eliminates some of the waves generated by the mode conversion. The discrete longitudinal wave is transformed in a diffusion wave. The discrete 
transversal wave is then time shifted and becomes the first wave due to the fault following the diffusion wave (Figure 3). The spectrum difference from the SWFT enhances the effect of the fault.

The speed at which this result is obtained makes this analysis method practical in fast quality control. The time at which the anomaly appears shows a possibility of the positionning or locating an impedance rupture at the origin of the echo. The theory of resonance can be used to dimension the faults (holes). It allows to link resonnance frequencies caused by a hole to its size through a constant which is equal to the celerity (speed) of the compression waves going through the fluid filling the hole.

\section{Conclusion}

The laser ultrasound technique has been efficient for conformity detection. In this work, we have used the generation mode by micro-ablation which gives a good acoustical level. The time-frequency-energy analysis combined with fitering methods allows to evaluate the conformity of parts to be tested through the SWFT spectrum difference between good and bad parts.

\section{References}

[1] EL MEKKI H, LONGUEMARD J.P "Acoustic wavezs from pulsed TEA CO2 laser and application to defect detection", The Bristish Journal of Non Destructive testing, for apparition.

[2] EL MEKKI H, DUBOIS M, LONGUEMARD J.P, TARRATS A, "Contrôle non destructif par ondes acoustique crées et détectées par laser", International Symposium on recent Advances in Surveillance Using Acoustical and Vibratory methods, 27-29 Octobre 1992, Senlis (France);

(3) MALLAT S.G, "A theory for multiresolution signal decomposition : The wavelet representation", IEEE Trans. on PAMI, vol.11, n7 pp.674-93, july 1989.

[4] RIOUL O, Fast algorithms for discrete and continious wavelet transforms", IEEE Trans. on Information Theory, vol 38, n)2, pp.569-86, March 1992.

[5] DAUBECHIES I, "Orthonormal bases of supported wavelets", Comm in Pure and Applied Math, vol.41, pp. 909-96, November 1988.

[6] UNAL M, "Transformée temps fréquence-énergie appliquées au contrôle non destructif sans contact", Mémoire de Maîtrise, Décembre 1993, Ecole Polytechnique de Montréal 


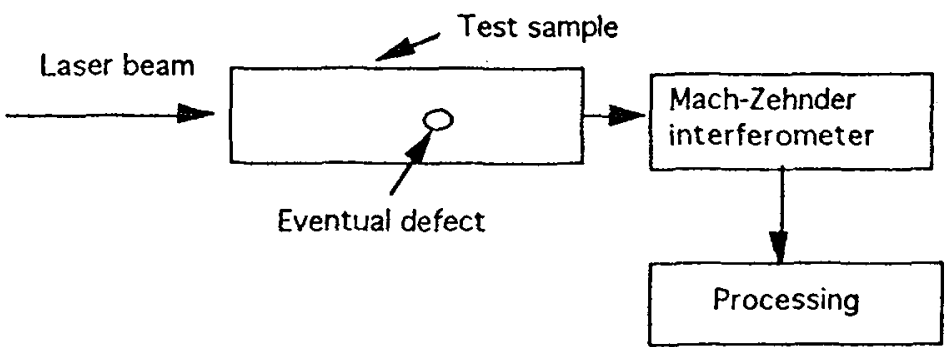

Figure 1

Measurement set-up

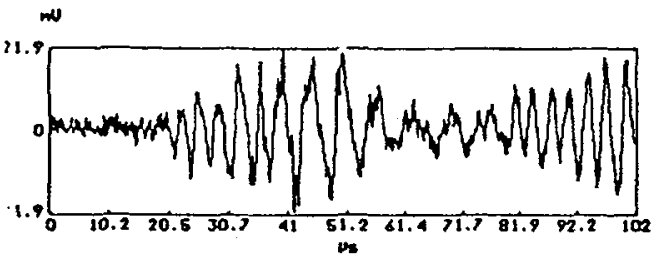

(a)
Figure 2

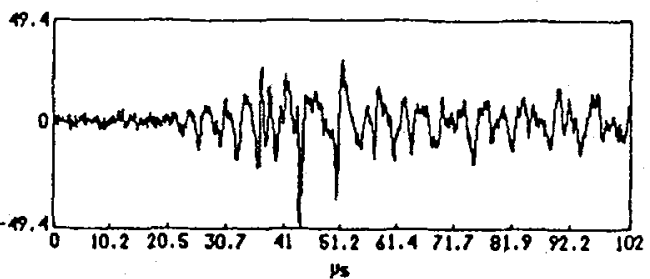

(b)

Acoustical signatures (a) without fault, (b) with fault of $3 \mathrm{~mm}$ in diameter (cylinder in duralumin : $I=100 \mathrm{~mm}, D=20 \mathrm{~mm}$ )

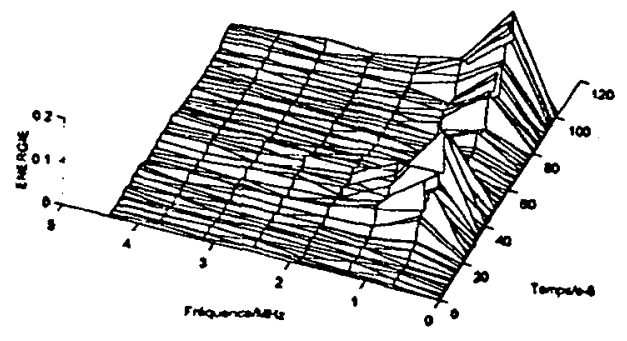

(a)

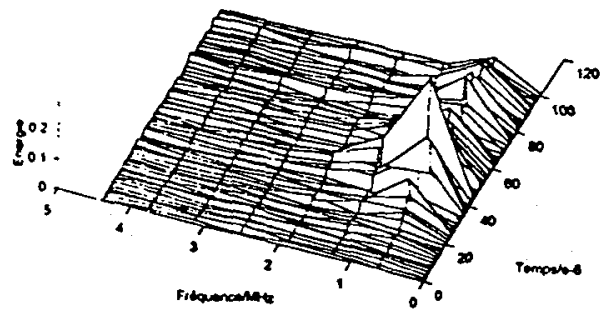

(b)

Figure 3

3-D SWFT analysis (a) (etc)

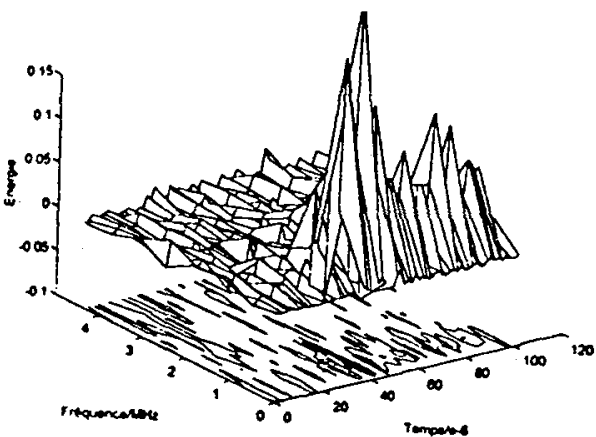

Figure 4

SWFT spectrum difference between a part without fault and a part with fault of $3 \mathrm{~mm}$ in diameter, cylinder in duralumin : $I=100 \mathrm{~mm}, d=20 \mathrm{~mm}$. 